\title{
Transportation Cost Optimization
}

\section{Bashkim Çerkini}

Kellogg and Brown \& Root, Ferizaj, Kosovë bashkimqerkini@gmail.com

Roberta Bajrami

University $A A B$, Ferizaj, Kosovë Roberta.Bajrami@universitetiaab.com

Robert Kosova

Faculty of Information Technology, Durrës, Albania robertko60@yahoo.com

Valentina Shehu

Faculty of Natural Science, Durrës, Albania shehuv@yahoo.com

\section{Doi:10.5901/ajis.2015.v4n2s1p42}

\section{Abstract}

\begin{abstract}
Many manufacturing make their products in few locations and ship them to many different locations. In this paper we use Evolver, Excel Solver and Microsoft Solver Foundation in order to optimize transportation cost or to find the cheaper way to make and ship products to the customers and meet customers' demands. "Proplast" company that manufactures doors and windows is located in three different places; in Ferizaj, Pristina and Prizren and supplies 9 shops in Kosovë, Albania, Macedonia, Montenegro and Serbia. Mathematically speaking, our goal is to find minimal transportation cost and this problem will be set up as a linear programming model with the below definition: * Minimize total production and transportation cost; * Constraints: -The amount shipped from each factory cannot exceed plant capacity, - Every shop must receive its required demand, - Transportation trucks have the limit of loading quantity and - Each shipping amount must be nonnegative. We will show Evolver, Excel Solver and Microsoft Solver Foundation results and will find the least expensive way. Also we will compare minimum and maximum cost for all software's.
\end{abstract}

Keywords: Transportation Cost, Optimization, Evolver, Excel Solver and MS Solver Foundation.

\section{Introduction}

In this paper we have chosen "Proplast" company that manufactures doors and windows in three different factories and transport its products in nine different shops as shown in the map and graph below:

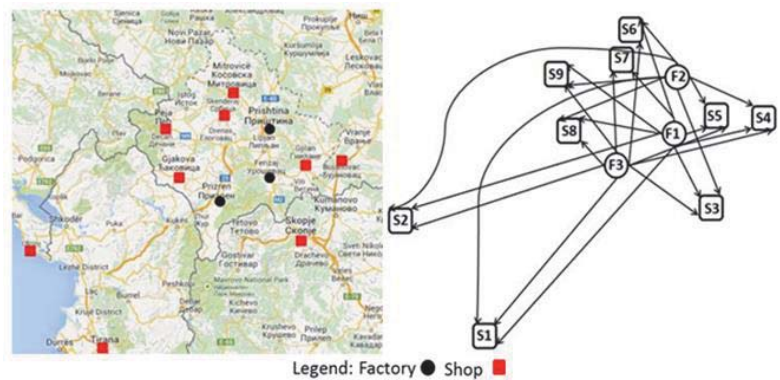

Figure 1. Distribution Network from Factory to the Shops 
We will utilize the power of Evolver, Microsoft Solver and Microsoft Solver Foundation in order to optimize transportation cost. Technically speaking our objective is to find a lowest logistical cost. Minimizing cost as optimization transportation problem is a classic problem in supply chain in the field of optimization. This problem is specifically essential in distribution and retail environments with the transportation management needs.

In the optimization of the supplier selection problem using discrete firefly algorithm is showing a firefly optimization based algorithm which helps to choose the proper suppliers in a case of given order quantity of a given product. The developed algorithm takes account of the minimum and maximum order quantities at the different suppliers as constraints. The algorithm takes account of the capacity and the cost of the used transport vehicles too. The article describes the operation of the algorithm and the penalty functions applied. In the last part the firefly algorithm and the solution given by the MS Excel solver's general reduced gradient and the evolutionary algorithm is compared.

\section{Minimizing Transportation Cost for Window and Door "Proplast" Company}

Mathematical expression for calculation transportation cost per unit is:

$\mathrm{C}=\left(\mathrm{ck}^{*} \mathrm{~L}\right) / \mathrm{m}$

C - Total cost

ck - Operator cost per $1 \mathrm{~km}$

$\mathrm{L}$ - Total length between factory and demand shop

m - Truck Loading Capacity

The total cost $(\mathrm{C})$ is in proportion with the length of the routes. Operator cost (ck) includes maintenance and direct costs of operation (driver wage, fuel consumption, tires, brake shoes, etc.). Vehicle depreciation costs are included as a part of operator cost too. All cost in this paper is calculated in Euro. Based on the mathematical formula and data's we will populate the table below with the transportation cost per unit:

Table 1. Transportation cost per unit from factories to the shops

\begin{tabular}{|c|cccccccccc|}
\hline Factory & \multicolumn{1}{|c|}{ S1 } & S2 & S3 & S4 & S5 & S6 & S7 & S8 & S9 \\
\hline F1 & 2.08 & 2.20 & 0.48 & 1.18 & 0.31 & 0.65 & 0.53 & 0.80 & 0.82 \\
F2 & 2.26 & 2.38 & 0.79 & 1.49 & 0.47 & 0.37 & 0.45 & 0.75 & 0.75 \\
\hline F3 & 1.58 & 1.70 & 0.89 & 1.58 & 0.88 & 0.92 & 0.73 & 0.33 & 0.88 \\
\hline
\end{tabular}

The mathematical model for this task will look as below:

$$
\operatorname{Min} \sum_{i}^{m} \sum_{j}^{n} C i j * S i j
$$

Constraints:

$$
\begin{array}{lll}
\sum_{j}^{n} S i j \leq F i & i=1, \ldots, \mathrm{m} & \mathrm{C}_{\mathrm{ij}} \text { - is cost per unit from factory i to shop } \mathrm{j} \\
\sum_{i}^{m} S i j=D j & \mathrm{j}=1, \ldots, \mathrm{n} & \mathrm{S}_{\mathrm{ij}} \text { - Shipment amount from factory } \mathrm{i} \text { to the shop } \mathrm{j} \\
\mathrm{Sij} \leq \max \mathrm{T} & \begin{array}{l}
i=1, \ldots, \mathrm{m} \\
\mathrm{j}=1, \ldots, \mathrm{n}
\end{array} & \mathrm{F}_{\mathrm{i}} \text { - Production capacity for factory } \mathrm{F}_{1}, \mathrm{~F}_{2} \text { or } \mathrm{F}_{3} \\
\mathrm{Sij} \geq 0 & \mathrm{D}_{\mathrm{j}} \text { - Shipment amount received in the shop } \mathrm{j} \\
& i=1, \ldots, \mathrm{m} & \text { Max } \mathrm{T} \text { - is maximal loading truck capacity }
\end{array}
$$

Transportation Cost Minimization will be calculated using Evolver, Excel Solver and MS Foundation and will set up with the below specifications:

- Target cell - Minimize total shipping cost.

- Changing cells - The amount made at every factory for shipping to every shop.

- Constraints

- Shipping amount from each factory cannot exceed production factory capacity

- Every demand point must receive at least its required demand

- Each changing cell cannot be negative.

Target Cell is in cell C25 named Total Min Cost. Changing cells are in the cells C17:H19. Constraints shown under column H named "Sent" H17:H19 are less or equal to "Capacity" in column K17:K19. Constraints in row 20 named 
"Received" are in the cells C20:G20 and are bigger or equal to row 22 named "Demand" in the cells C22:G22 which contains demands for each shop. Column K named "Capacity" in the cells K17:K19 is production capacity for each factory and C23 is Maximum truck transportation capacity.

Demand amount for each shop is on weekly bases. Each factory has only one heavy truck with maximum capacity of 500 units. Each factory have maximum production capacity on weekly bases; maximum capacity for factory F1 is 1300 units, maximum capacity for factory F2 is 1100 units and maximum capacity F3 is 1000 units. All above constrains are entered into Excel table below.

Table 2. Target Cell, Changing Cells and Constrains

\begin{tabular}{|c|c|c|c|c|c|c|c|c|c|c|c|c|c|}
\hline & \multicolumn{10}{|c|}{ Shipments } \\
\hline & B & C & D & E & F & D & H & E & F & G & H & I & K \\
16 & & S1 & S2 & S3 & S4 & S5 & S6 & S7 & S8 & S9 & Sent & & Capacity \\
\hline 17 & F1 & 0 & 0 & 300 & 250 & 275 & 0 & 0 & 150 & 0 & 975 & $<=$ & 1300 \\
\hline 18 & F2 & 0 & 0 & 0 & 0 & 0 & 325 & 375 & 275 & 125 & 1100 & $<=$ & 1100 \\
19 & F3 & 500 & 475 & 0 & 0 & 0 & 0 & 0 & 25 & 0 & 1000 & $<=$ & 1000 \\
\hline 2 & Received & 500 & 475 & 300 & 250 & 275 & 325 & 375 & 450 & 125 & & & \\
21 & & $>=$ & $>=$ & $>=$ & $>=$ & $>=$ & $>=$ & $>=$ & $>=$ & $>=$ & & \\
22 & Demand & 500 & 475 & 300 & 250 & 275 & 325 & 375 & 450 & 125 & & & \\
\hline 23 & Max Truck Capacity & 500 & & & & & & & & & & & \\
\hline 24 & & & & & & & & & & & & & \\
\hline 25 & Total Min Cost & $\mathbf{2 , 8 4 2 . 3 8}$ & & & & & & & & & & & \\
\hline
\end{tabular}

Total minimum cost of 2,842.38 shown in cell C25 in above table is the same from three methods: Evolver, Excel Solver and MS Foundation.

\subsection{Optimization with Evolver}

Evolver is an advanced, yet simple-to-use optimization add-in for Microsoft Excel. Evolver uses inventive genetic algorithm (GA) and linear programming technology to quickly solve problems in finance, distribution, resource allocation, manufacturing, engineering, and more. Practically any kind of problem that can be modeled in Excel can be solved by Evolver, including otherwise impossible, complex nonlinear problems. After we get all constrains entered in evolver model and run the software we get the total minimal cost equal to 2,842.38.

Adjustable Cells and Hard Constrains are shown below:

Table 3. Adjustable Cells

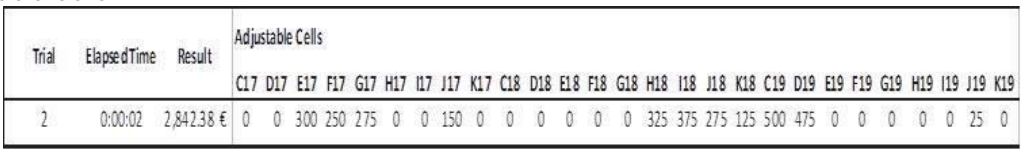

Table 4. Hard Constraints

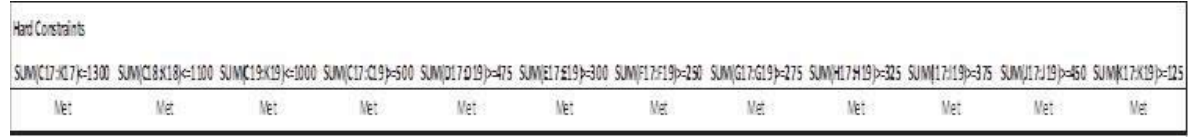

\subsection{Optimization with Excel Solver}

Excel Solver is part of a suite of commands sometimes called what-if analysis tools. With Solver, you can find an optimal (maximum or minimum) value for a formula in one cell - called the target cell - subject to constraint, or limit, on the values of other formula cells on a worksheet. Solver works with a set of cells, called Changing cells or Adjustable cells that participate in computing the formulas in the objective and constraint cells. Solver adjusts the values in the changes cells to satisfy the limits on constraint cells and produce the result we want for the target cell.

Table 1 and 2 will be used again in the Excel Solver. In below tables are shown Answer, Sensitivity and Limits report of the Microsoft Excel Solver. 
Table 5. Answer Report

\begin{tabular}{|c|c|c|c|}
\hline \multicolumn{4}{|c|}{ Target Cell (Min) } \\
\hline Cell & Name & Original Value & Final Value \\
\hline$\$ C \$ 25$ & Total Min Cost >= & $2,842.38$ & $2,842.38$ \\
\hline \multicolumn{4}{|c|}{ Adjustable Cells } \\
\hline Cell & Name & Original Value & Final Value \\
\hline$\$ C \$ 17$ & F151 & 0 & 0 \\
\hline$\$ D \$ 17$ & $F 152$ & 0 & 0 \\
\hline \$E\$17 & F1S3 & 300 & 300 \\
\hline \$F\$17 & F154 & 250 & 250 \\
\hline$\$$ G\$17 & F155 & 275 & 275 \\
\hline$\$ H \$ 17$ & F156 & 0 & 0 \\
\hline$\$ 1 \$ 17$ & F157 & 0 & \\
\hline$\$ \$ 17$ & F158 & 150 & 150 \\
\hline$\$ K \$ 17$ & F1S9 & 0 & 0 \\
\hline$\$ C \$ 18$ & F2S1 & 0 & 0 \\
\hline$\$ D \$ 18$ & $F 252$ & 0 & \\
\hline SE\$18 & F253 & 0 & 0 \\
\hline$\$ F \$ 18$ & $F 254$ & 0 & 0 \\
\hline$\$ G \$ 18$ & F2S5 & 0 & \\
\hline$\$ H \$ 18$ & F256 & 325 & 325 \\
\hline$\$ 1 \$ 18$ & F2S7 & 375 & 375 \\
\hline$\$ \$ 18$ & $F 258$ & 275 & 275 \\
\hline$\$ K \$ 18$ & F259 & 125 & 125 \\
\hline$\$ \mathrm{C} \$ 19$ & F351 & 500 & 500 \\
\hline$\$ 0 \$ 19$ & F3S2 & 475 & 475 \\
\hline SE\$19 & F3S3 & 0 & \\
\hline \$F\$19 & F354 & 0 & 0 \\
\hline$\$ G \$ 19$ & 7355 & 0 & 0 \\
\hline$\$ H \$ 19$ & $F 356$ & 0 & 0 \\
\hline$\$ \$ 19$ & F357 & 0 & 0 \\
\hline$\$ \$ 19$ & F358 & 25 & 25 \\
\hline \$K\$\$19 & $F 359$ & 0 & 0 \\
\hline
\end{tabular}

Table 6. Limits Report

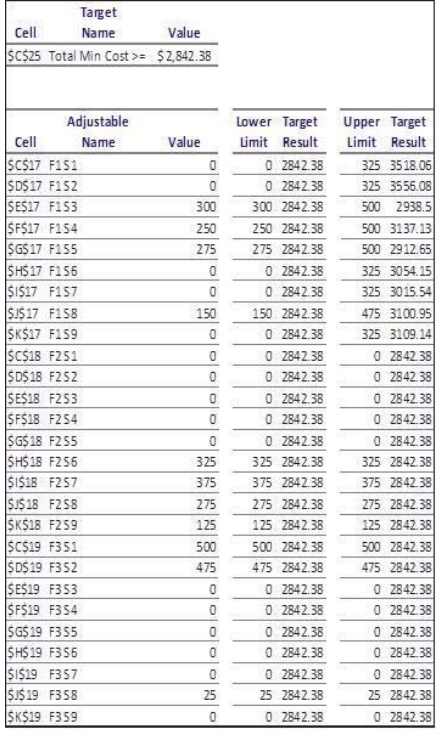

Table 7. Sensitivity Report

\begin{tabular}{|c|c|c|c|c|c|c|}
\hline \multicolumn{7}{|c|}{ straints } \\
\hline Cell & Name & $\begin{array}{l}\text { Final } \\
\text { Value }\end{array}$ & $\begin{array}{c}\text { Shadow } \\
\text { Price }\end{array}$ & $\begin{array}{l}\text { Constraint } \\
\text { R.H.Side }\end{array}$ & $\begin{array}{l}\text { Allowable } \\
\text { Increase }\end{array}$ & $\begin{array}{l}\text { Allowable } \\
\text { Decrease }\end{array}$ \\
\hline$\$ C \$ 20$ & Received S1 & 500 & 2.079 & 500 & 325 & 5 \\
\hline SD\$20 & Received S2 & 475 & 2.1645 & 475 & 25 & 150 \\
\hline SES 20 & Received 53 & 300 & 0.4806 & 300 & 200 & 300 \\
\hline SF\$20 & Received S4 & 250 & 1.179 & 250 & 250 & 250 \\
\hline$\$ G \$ 20$ & Received S5 & 275 & 0.3123 & 275 & 225 & 275 \\
\hline$\$ H \$ 20$ & Received S6 & 325 & 0.4158 & 325 & 175 & 150 \\
\hline$\$ 1 \$ 20$ & Received 57 & 375 & 0.4977 & 375 & 125 & 150 \\
\hline SI\$20 & Received 58 & 450 & 0.7956 & 450 & 325 & 150 \\
\hline SK\$20 & Received S9 & 125 & 0.7911 & 125 & 275 & 125 \\
\hline SLS17 & F1 Sent & 975 & 0 & 1300 & $1 E+30$ & 325 \\
\hline SLS18 & F2 Sent & 1100 & -0.045 & 1100 & 150 & 275 \\
\hline SLS19 & F3 Sent & 1000 & -0.4635 & 1000 & 150 & 25 \\
\hline \multicolumn{7}{|c|}{ Adjustable Cells } \\
\hline Cell & Name & $\begin{array}{l}\text { Final } \\
\text { Value }\end{array}$ & $\begin{array}{c}\text { Reduced } \\
\text { Cost }\end{array}$ & $\begin{array}{l}\text { Objective } \\
\text { Coefficient }\end{array}$ & $\begin{array}{l}\text { Allowable } A \\
\text { Increase }\end{array}$ & $\begin{array}{c}\text { Allowable } \\
\text { Decrease }\end{array}$ \\
\hline SC\$17 & $7 \mathrm{~F} 1 \mathrm{S1}$ & 0 & 0 & 2.079 & 0.225 & 0.0315 \\
\hline \$D\$17 & $7 \mathrm{~F} 1 \mathrm{~S} 2$ & 0 & 0.0315 & 2.196 & $1 E+30$ & 0.0315 \\
\hline SES17 & $7 F 153$ & 300 & 0 & 0.4806 & 0.3582 & 0.4806 \\
\hline \$F\$17 & $7 F 154$ & 250 & 0 & 1.179 & 0.36 & 1.179 \\
\hline \$G\$17 & $7 \mathrm{~F} 1 \mathrm{S5}$ & 275 & 0 & 0.3123 & 0.207 & 0.3123 \\
\hline SHS17 & $7 \mathrm{~F} 1 \mathrm{~S} 6$ & 0 & 0.2358 & 0.6516 & $1 E+30$ & 0.2358 \\
\hline \$\$\$17 & F1S7 & 0 & 0.0351 & 0.5328 & $1 E+30$ & 0.0351 \\
\hline \$J\$\$17 & 7 F1s 8 & 150 & 0 & 0.7956 & 0.0297 & 0.045 \\
\hline \$K\$17 & $7 \mathrm{~F} 159$ & 0 & 0.0297 & 0.8208 & $1 E+30$ & 0.0297 \\
\hline$\$ \operatorname{c\$ 18}$ & $8 F 2 S 1$ & 0 & 0.225 & 2.259 & $1 E+30$ & 0.225 \\
\hline SD\$18 & $8 \mathrm{~F} 2 \mathrm{~S} 2$ & 0 & 0.2565 & 2.376 & $1 E+30$ & 0.2565 \\
\hline SES18 & $8 \mathrm{~F} 2 \mathrm{S3}$ & 0 & 0.3582 & 0.7938 & $1 E+30$ & 0.3582 \\
\hline SF 18 & $8 F 2 S 4$ & 0 & 0.36 & 1.494 & $1 E+30$ & 0.36 \\
\hline$\$$ S\$18 & $8 F 255$ & 0 & 0.207 & 0.4743 & $1 E+30$ & 0.207 \\
\hline \$H\$18 & $8 \mathrm{~F} 2 \mathrm{~S} 6$ & 325 & 0 & 0.3708 & 0.2358 & 0.4158 \\
\hline$\$ 1 \$ 18$ & 3 F2S7 & 375 & 0 & 0.4527 & 0.0351 & 0.4977 \\
\hline$\$ \$ 18$ & $3 F 258$ & 275 & 0 & 0.7506 & 0.045 & 0.0297 \\
\hline SKS18 & $8 \mathrm{~F} 259$ & 125 & 0 & 0.7461 & 0.0297 & 0.7911 \\
\hline $\operatorname{scs} 19$ & $9 \mathrm{~F} 3 \mathrm{~S} 1$ & 500 & -0.0315 & 1.584 & 0.0315 & $1 E+30$ \\
\hline SDS19 & 9 F $3 S 2$ & 475 & 0 & 1.701 & 0.0315 & 2.1645 \\
\hline SE\$19 & $9 \mathrm{~F} 3 \mathrm{S3}$ & 0 & 0.8712 & 0.8883 & $1 E+30$ & 0.8712 \\
\hline$\$ F \$ 19$ & $9 \mathrm{~F} 3 \mathrm{S4}$ & 0 & 0.8685 & 1.584 & $1 E+30$ & 0.8685 \\
\hline \$G\$19 & 9 F3S5 & 0 & 1.0278 & 0.8766 & $1 E+30$ & 1.0278 \\
\hline SHS19 & $9 F 356$ & 0 & 0.9657 & 0.918 & $1 E+30$ & 0.9657 \\
\hline$\$ \$ \$ 19$ & F357 & 0 & 0.6912 & 0.7254 & $1 \mathrm{E}+30$ & 0.6912 \\
\hline SIS19 & $9 F 358$ & 25 & 0 & 0.3321 & 0.4635 & 0.0315 \\
\hline \$K\$19 & 9 F3Sg & 0 & 0.5526 & 0.8802 & $1 E+30$ & 0.5526 \\
\hline
\end{tabular}




\subsection{Optimization with Microsoft Foundation Solver}

Microsoft Solver Foundation is a set of advance tools for mathematical simulation, optimization and modeling that relies on a managed execution environment and the common language runtime (CLR).

Solver Foundation OML (Optimization Modeling Language) with constrains is shown below:

Model [ Parameters[ Sets[Any], SRC, DST ], Parameters[ Reals[-Infinity, Infinity], Cost [SRC, DST] ], Decisions [ Reals[0, 500], Shipments[SRC, DST] ], Constraints[ Constraint1 ->

Shipments[0,0]+Shipments[0,1]+Shipments $[0,2]+$ Shipments $[0,3]+$ Shipments $[0,4]+$ Shipments $[0,5]+$ Shipments $[0,6]+$ Shipments[0,7]+Shipments[0,8]<=1300,

Constraint2 $->$

Shipments[1,0]+Shipments[1,1]+Shipments[1,2]+Shipments[1,3]+Shipments[1,4]+Shipments[1,5]+Shipments[1,6]+ Shipments[1,7]+Shipments[1,8]<=1100,

Constraint3 ->

Shipments[2,0]+Shipments[2,1]+Shipments[2,2]+Shipments[2,3]+Shipments[2,4]+Shipments[2,5]+Shipments[2,6]+ Shipments[2,7]+Shipments[2,8]<=1000,

Constraint4 -> Shipments $[0,0]+$ Shipments $[1,0]+$ Shipments $[2,0]>=500$,

Constraint5 -> Shipments[0,1]+Shipments[1,1]+Shipments[2,1]>=475,

Constraint6 -> Shipments[0,2]+Shipments[1,2]+Shipments[2,2]>=300,

Constraint7 -> Shipments[0,3]+Shipments[1,3]+Shipments[2,3]>=250,

Constraint8 -> Shipments[0,4]+Shipments[1,4]+Shipments[2,4]>=275,

Constraint9 $>>$ Shipments[0,5]+Shipments $[1,5]+$ Shipments $[2,5]>=325$,

Constraint10 $>>$ Shipments $[0,6]+$ Shipments $[1,6]+$ Shipments $[2,6]>=375$,

Constraint11 $>>$ Shipments $[0,7]+$ Shipments $[1,7]+$ Shipments $[2,7]>=450$,

Constraint12 -> Shipments[0,8]+Shipments[1,8]+Shipments[2,8]>=125],

Goals[ Minimize[ TotalCost -> Annotation[Sum[\{i, SRC\}, \{j, DST\}, Cost[i, j]*Shipments[i,j]], "order", 0] ] ] ] After all solver foundation parameters and OML are entered we get results as below:

Table 8. Solver Foundation Results

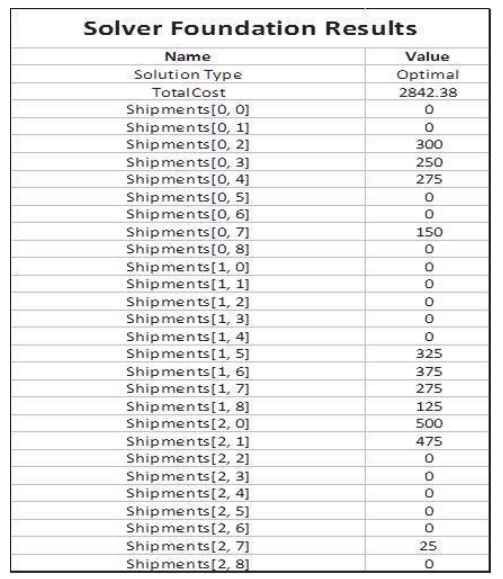

When Optimization Goal is changed to Maximum in cell C25 we will get Maximum Transportation cost of 4,816.31 Euro for Evolver, Excel Solver and Microsoft Foundation.

\section{Comparison between Minimal and Maximal Total Cost}

Below chart shows minimal and maximal cost for Evolver, Excel Solver and Microsoft Foundation Solver. We have same cost in all three software. Maximal cost for all three software's are around $70 \%$ higher than minimal cost. Using optimal distribution network will impact cost and time saving. 


\section{Total Transportation Cost}

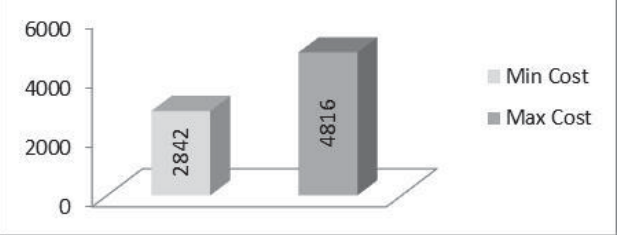

Figure 2. Comparison between Minimal and Maximal Cost

\section{Conclusion}

Logistical route system is flexible based on the circumstances and demands. Optimization problems in many fields can be modeled and solved using Evolver, Excel Solver or Microsoft Foundation Solver. In this paperwork we have used them to resolve logistical route optimization problem in order to reduce transportation cost. Matrices range in this paperwork is $3 \times 9$ but the same procedure can be applied in the cases with higher range of the matrices $\mathrm{N} \times \mathrm{M}$. Optimization problems in general are real world problems, we meet in many fields such as mathematics, science, engineering, business or finances. In this matter, we find the optimal or most efficient way of using limited resources to reach objective of the situation. In this paperwork the main goal is to maximize profit, minimize cost, minimizing the total distance travelled and using this can be done very well by using Evolver, Excel Solver and Microsoft Foundation Solver.

\section{References}

Andrew J. Mason. Solving Linear Programs using Microsoft EXCEL Solver

B. Çerkini, V. Prifti, R. Kosova. Logistical Route Optimization to Reduce Transportation Cost, Conference ICCSIS2014 in Durres

B. Parker and D. Caine. Minimizing Transportation Costs: An Efficient and Effective Approach for the Spreadsheet User

Edwin K.P. Chong and Statislaw H. Zak. An introduction to Optimization, Third Edition

Leslie Chandrakantha. Using Excel Solver in Optimization Problems

http://lpsolve.sourceforge.net/5.5/MSF.htm, Using Excel Solver from Microsoft Solver Foundation, 15 January 2015

http://msdn.microsoft.com/en-gb/devlabs/hh145003.aspx, Microsoft Solver Foundation, 05 January 2015

http://www.codeproject.com/Tips/744558/CSP-Programming-of-Microsoft-Solver-Foundation, Code Project, 02 February 2015

http://office.microsoft.com/en-us/excel-help/using-solver-to-solve-transportation-or-distribution-problems-HA001124597.aspx,

Using Solver to Solve Transportation or Distribution Problems, 29 January 2015

http://www.palisade.com/evolver/, Find the Best Solutions to any Optimization Problem, 10 February 2015

https://support.office.com/en-za/article/Define-and-solve-a-problem-by-using-Solver-9ed03c9f-7caf-4d99-bb6d-078f96d1652c,

Define and Solve a Problem by Using Solver, 08 February 2015

https://msdn.microsoft.com/en-us/library/ff524509\%28v=vs.93\%29.aspx, Microsoft Solver Foundation 3.1, 17 January 2015

K. László. Optimization of the Supplier Selection Problem Using Discrete Firefly Algorithm 